\title{
The Phenomena about the Impact of TKI Migration on Their Children's Education at Sambelia District of East Lombok Regency, Indonesia
}

\author{
* Reno Yandhora Sari ${ }^{1)}$ and Afdhal ${ }^{2)}$
}

1) Student Geography of Science, Padang State University, INDONESIA

2) Department of Geography, Universitas Negeri Padang-INDONESIA

Email: renoysari@gmail.com

*Corresponding Author, Received: January 15, 2018, Revised: March 02. 2018, Accepted: May 20, 2018

\begin{abstract}
This study was aimed to know the impact of the migration of Indonesian worker (referred as TKI) family on children's education at Sambelia District of East Lombok Regency. This research using qualitative approach. Collecting data technique were observation, interview and documentation. The type of the data are primary and secondary data. Primary data collected by respondent interviews and secondary data collected by state government. To analyze the data, the researcher using qualitative model by Miles and Huberman: data reduction, display data, and conclusion. Other data analysis such as government policy and raw data from state government of East Lombok using AHP Model and statistic analysis. The result found that $40 \%$ of children whose parents were TKI suffered from poor psychosocial development in terms of achievement and not having close friend. A long-term impact was that those children might drop out of school and more likely experienced psychological wellbeing disorders like emotional disorder. Children from TKI family who grew and developed with only one of the parents tended to be more disobedient. They tended to skip school and chose to spend time for playing. According to the score of Consistency Ratio, the highest score was obtained by factor of socioeconomy (0.373) followed by factor of poor life skill $(0.277)$, factor of not being accepted in the environment (0.205), and factor of higher life necessities (0.146).
\end{abstract}

Keywords: TKI, Children's Education

\section{Introduction}

The phenomena of migration is often found in developing countries like at some regions in Indonesia, especially in the context of workers that migrate from rural to urban areas. Internal migration is seen as a natural process which transfers workers from regions to modern industrial sectors with higher labor absorption in cities, although in fact the flow of labor migration from rural areas has exceed the level of job creation. In other words, the migration goes far beyond the absorption of industrial and service sector in urban area (Sulaiman, 2015). The main reason of people migration from village to city is due to economic reason. This motive is caused by economic disparity between regions. This condition is the most rational reason for an individual to move to cities in the hope of getting a better job and earning a higher income than what is earned in the village. One of the phenomena was found in East Lombok Regency. According to local government's data, East Lombok was recorded as the regency that exported largest workers abroad with a total of more than 15,000 workers in 2016 (BPS, 2016).

Due to factor of least employment in Indonesia, they are motivated to look for a job or become TKI in other countries such as in Malaysia, Saudi Arabia, Brunei Darussalam and Korea. According to some people, 
this choice is a right solution that helps them fulfilling their life necessities including the children's needs of education. Based on 2014 data from Central Bureau Statistics of Nusa Tenggara Barat Province, it was recorded that in 2014 there were 44,054 people of NTB who worked abroad, consisting of 29,499 male workers and 14,485 female workers. 124 workers were from Martaram City, 4,050 were from West Lombok Regency, 9,287 were from Central Lombok, 818 were from North Lombok, 23,417 were from East Lombok, 1,390 were from Kota Bima, 3,454 were from Sumbawa Regency, 646 were from West Sumbawa, 731 were from Dompu, and 1,709 workers were from Bima. East Lombok Regency was recorded as the sender with largest TKI from NTB compared to other regions in Indonesia (BPS, 2014). For example, at Sambelia District of East Lombok there were 733 TKI who worked in Malaysia, Brunei Darussalam and Saudi Arabia. This is not a new thing for Sambelia Village. From 1990 to 2008, the numbers of TKI sent abroad had been increasing over each period of time. The following data shows that working as TKI abroad is still a better job alternative compared to working in their own village.

The majority of migrant workers are male. Almost every house has at least a family member who works abroad as a domestic, agricultural worker and other blue-collar workers (Nopitasari and Johana, 2017). According to the research in Yayasan Tunas Alam Indonesia in 2015, in the village there were more than 350 children (ages of 0 to 18) with their parent/s left to work abroad in countries such as Malaysia, Brunei Darussalam, Saudi Arabia and other Middle East Countries. The almost same number was also found in the neighboring villages. Socio-economic condition in the hometown and individual's desire to improve their standard of living for fulfilling the needs motivate people to work in other promising places. Since every individual has different need, the assessment on each individual's origin is different and decision-making process to move (mobility) is also different (Purnomo, 2009).

The needs of each human being are different. It is due to social status of an autonomy that migh be high, middle and low. For those whose socio-economy status is high, they can easily fulfill their needs of food, shelter, clothing, and especially their children's education. On the contrary, those who have a low socioeconomic status might be able to fulfill only their needs of food and clothing. As the ones responsible for their children's education, parents should care about continuity of the education for the sake of developing children's potential/ability. Children' provision of education/knowledge is hoped to be useful for their lives. Education is very important for children's further growth and development and meant to develop their potential and ability. Many children in Sambelia Village are given chance to get education. However, the condition of surrounding environment does not support them.

Education is inseparable from life of human as an individual and social living being. Education for human's life is an absolute necessity which must be fulfilled throughout life. Without Education, it is impossible for a group of people to live and develop in line with aspirations (ways) of being advanced, prosperous, and happy in life according to their concept of view of life. children born in TKI family were identified to be susceptible to social problems. Generally. they mostly had problem with their friends of the same age. This phenomenon is the result of changes in child care pattern in the family and due to parents' departure, especially mother's, to other countries (BKKBN, 2013).

\section{Method}

This research used a qualitative approach. One of the reasons for choosing this approach is that this method can be used to uncover and understand what is hidden behind a phenomena which is sometimes hard to be fully understood. This research was set at Sambelia District of East Lombok Regency. The research data was collected through observation, interview using interview guideline, and documentation. Primary data was collected through deep interview with respondents and observation. Meanwhile, secondary data was obtained through documentation from BKKBN (national population and family planning agency), Central Bureau Statistics of NTB, and newspaper. Informants in this research were local people of Sambelia District. The technique being used to analyze the data of the impact of migration on children's education was Miles and Huberman's analysis technique (Miles et al. 1994). Other data analysis such as government policy and raw data from state government of East Lombok using AHP Model and statistic analysis (Hermon, 2014; Hermon, 2017). 


\section{Results and Discussion}

\section{The Impact of Migration on Children's Education in Sambelia District of East Lombok Regency}

TKI (Indonesian workers) are Indonesian citizens who are qualified to work abroad at any given time and given payment. A great attention is paid to TKI because they do not get proper protection and social security. However, not only the fate of TKI that needs attention but also the children of TKI need special attention because they are vulnerable and often put in a condition of a low life quality. More than 350 children in East Lombok Regency of Nusa Tenggara Barat were forced to be in a condition without parent's or parents' care. East Lombok was noted as one of regencies that had exported more than 15,000 informal workers to Middle East countries, Malaysia, Brunei Darussalam, and Hongkong. Males mostly became migrant workers while females became nomads (BKKBN. 2013). The data obtained by researcher from Central Bureau Statistics of East Lombok Regency showed that there were 25 school dropouts in 2016 due to their mischievousness in school environment. They also lack the affection and attention from their parents because the parents were working in Malaysia. The data can be seen in the following table:

Table 1. The Number of School Dropouts at Sambelia District in 2016

\begin{tabular}{cc} 
Educational Level & Total \\
\hline Elementary School & 2 \\
Junior High School & 14 \\
Senior High School & 6 \\
Vocational High School & 3 \\
Total & 25 \\
\hline : Central Bureau of Statistics of East Lombok Regency, 2016
\end{tabular}

The decision made by some TKI has caused their children in Indonesia to be dropped out of school and lose the right to parental care and protection. Parents are responsible for caring, nurturing, educating and protecting their children. Event though those responsive can be entrusted to other family members, parents especially mother are still the main important figure for children's growth and development. Substitute parents (grandparents) are often not optimal in parenting because they have limited time and energy ( UU RI Nomor 23 , 2012). Bringing their children abroad is one of their efforts to be responsible parents and might be due to unavailable family members that can take care of their children. However, even after following their parents, the children are also difficult to attend school and get an equitable access to need fulfillment. CLC SD (Community Learning Center Sekolah Dasar), SIKK (Sekolah Indonesia Kota Kinabalu), and Humana is a good news for TKI and their children who stay abroad. These three educational institutions provide services for children to have the right to education weather it is formal or informal. The impact of parents' profession as TKI on their children education in East Lombok Regency suggested that about $40 \%$ of TKI children have a poor psychosocial development in terms of achievement and not having close friend.

\section{The Phenomena about the Impact of TKI Family's Migration on Children's Education at Sambelia District of East Lombok Regency}

Migration is an act of one's or group's moving from a geographic territory to other territory through crossing political or administrative borders with an intent of living temporarily or for unlimited time. One of human migration is worker migration. In 2007, Indonesia had exported about 2.7 million of TKI to countries such as Malaysia, Saudi Arabia, Taiwan, Singapura, South Korea, and United Arab Emirates (BNP2TKI, 2014). Education is teaching-learning process that results in the changing of expected attitude. After being born, children are learning in order to adapt to the environment and fulfill their needs. In islamic perspective about human educational development, children's islamic education can be developed since in the womb. The reason is because in fact human formation has been started since fetus and the time God breathed a soul into human body. Education is not only assumed as an effort to give information and develop skills but it has broader scope of function including as an effort to realize wishes, fulfill needs, and develop individual's ability so that a satisfying individual and social life pattern can be created. Education does not only serve as a facility 
for future life preparation but also for children's present life which is going towards adulthood. When a TKI migrates to work abroad, their children are entrusted to one of parents. When father become a migrant worker, mother should play double roles in nurturing and taking care of their children. It can cause stress in physic, economy and emotion that will affect her parenting and care for the children (Lan et al., 2014).

Other than her domestic role, a wife also must work in public sector such as farming, vending, and collecting rubber tree sap to first meet the daily needs when transfer money is slow. Parents' migration has a negative effect on children's school attendance. In the future, the children who are long left by their migrant parents will be likely dropped out school (Giannelli and Mangiavacchi, 2010). They are vulnerable to experience psychological wellbeing disorders for example emotional disorder compared to children who live with their parents (Graham and Jordan, 2017). Children from TKI family who live and develop with incomplete parent tend to be more disobedient. Many of them skip school and choose to spend most of their time for playing around. Substitute parents from other family members of TKI face difficulty in controlling the children's behavior because they can not freely treat them. This phenomena was explained in a interview between their researcher and TKI family in Sambelia District (Mastur, 2017).

The longer migrant parents separate from the children, the longer the absence of parents role in children selves. Gradually, parents role will be substituted by other family members that will become the primary caregiver of the children. Children who are left by their parent/s will be lonely and have poor achievement in school compared to their friends because they still emotionally and economically depend on parents. They felt abandoned and rejected and these negative feelings often arise although they have received money from their parents (Battistela, 1996). There are many factors that affect parents' decision in Sambelia District of East Lombok Regency to work abroad that left their children in their country such as: (1) Factor of low socio-economy, (2) Factor of not being accepted in the environment, (3) Factor of higher life necessities, and (4) Factor of poor life skill/ability. To see the value of consistency ratio of each factor, an AHP analysis was adopted. In AHP data processing, the easiest way to do the scoring is by using a computer program (Expert Choice). Factor of socio-economy is economic demands that make parents decide to be TKI whose payment is bigger than the one in their home regions so that they can fulfill their life necessities. Low life skill also become one of the factors. Low quality of human resources is caused by low education, health, and cultural problem (culture of property). Life skill is very important to improve human resources quality.

\section{Conclusion}

The impact of TKI parents on children's education at East Lombok Regency were that $40 \%$ of TKI's children suffered from poor psychosocial development in the terms of achievement and not having close friend. Their children in Indonesia must lose the right to parental care and protection. Parents are responsile for nurturing, taking care of, educating, and protecting their children. Although these responsibilities can be entrusted to other family members, parents especially mother are the main figures in children's growth and development. Subtitute parents (grandparents) are often not optimal at taking care of the children because they have limited time and energy. Parents migration negatively affects children attendance in school and the longterm effect is becoming school dropouts.

\section{References}

Battistela, Graziano and Ma. Cecillia Gastardo Conaco. (1996). Impact of Migration on the Children Left Behind. Asian Migrant (9) 3.

BNP2TKI. (2014). Migrasi Tenaga Kerja. Pemprov NTB

BKKBN. (2013). Anak Keluarga TKI Rawan Mengidap Masalah Sosial. Pemprov NTB

BPS. (2010). Kabupaten Lombok Timur dalam Angka. Pemprov NTB

BPS. (2014). Provinsi Nusa Tenggara Barat Dalam Angka: Pemprov NTB 
BPS. (2016). Kabupaten Lombok Timur dalam Angka. Pemprov NTB

Giannelli GC, and Mangiavacchi L. (2014). Children's schooling and parental migration: empirical evidence on the 'left-behind' generation in Albania. Review of Labour Economics and Industrial Relations [Internet]. 2010 Nov 24 [cited 2017 Sep 02];24(1):76-92. Improving Student's Achievement of Social Science by Using Jigsaw Cooperative Learning Model at Primary School. IOSR Journal of Research \& Method in Education (IOSR-JRME) e-ISSN: 2320-7388,p-ISSN: 2320-737X Volume 5, Issue 4 Ver. II (Jul - Aug. 2015), PP 01-07.

Graham E, and Jordan LP. (2017). Migrant Parents and the Psychological Well-Being of Left-Behind Children in Southeast Asia. Journal of Marriage and The Family [Internet]. 2011 [cited 2017 Sep 02];73(4):76387.

Hermon, D. (2014). Geografi Bencana Alam. Radjawali Press.

Hermon, D. (2017). Climate Change Mitigation. Rajawali Pers (Radjagrafindo). Jakarta.

Lan, A.H., Lam,T.,A,B.S., and Graham, E (2014). Transnational Migration, Changing Care Arrangements and Left Behind Children's Responses in South-East Asia. Children Geographies, 263-277.22 Maret, 2016.

Mastur, (2017). Ekonomi Keluarga TKI dan Pendidikan Anak di Desa Bagik Polak Barat Kecamatan Labuapi Kabupaten Lombok Barat Tahun 2017- 2018. Jurnal Pendidikan Dasar. Volume 1 No 1, Maret 2017. ISSN 2579-6194; 115-134. STIT Darussalimin NW Sengkol Mantang Praya Lombok Tengah.

Miles,M.B and Huberman, A,M. (1994). Analisis Data Kualitatif (Buku Sumber tentang metode metode baru) Terjemahan oleh Tjetjep Rohendi Rohidi, Jakarta : Universitas Indonesia.

Nopitasari, Rika., Imelda, and Johana D. (2017). Perlindungan dan Kesejahteraan Anak : Studi Deskriptif Pada Keluarga Tenaga Kerja Indonesia (TKI) Laki-Laki di Lombok Timur. Jurnal Ilmu Kesejahteraan Sosial. JILID 18, NOMOR 1, APRIL 2017, 18-33.

Purnomo, Didit. (2009). Fenomena Migrasi Tenaga Kerja dan Perannya Bagi Pembangunan Daerah Asal: Studi Empiris di Kabupaten Wonogiri. Jurnal Ekonomi Pembangunan Vol.10. No.1 Juni 2009. Hal 84-102. Fak Ekonomi Universitas Muhammadiyah Surakarta.

Sulaiman. (2015). Pengaruh Jumlah Anggota Keluarga dan Tingka Pendapatan Ekonomi Keluarga TKI Terhadap Kelangsungan Pendidikan Anak di Desa Penedagnador Kecamatan Labuahan Haji Lombok Timur. Jurnal Gnecwara Vol.9 No 2. September 2015. FKIP Universitas Gunung Rinjani.

Undang Undang RI No 6. (2012). Pengesahan Internasional Convention on The Protection of the Rights of All Migrant Workers and Members of Their Families (Konvensi Internasional Mengenai Perlindungan Hak-Hak Seluruh Pekerja Migran dan Anggota Keluarganya). Jakarta: Pemerintah Indonesia; 2 Mei 2012 